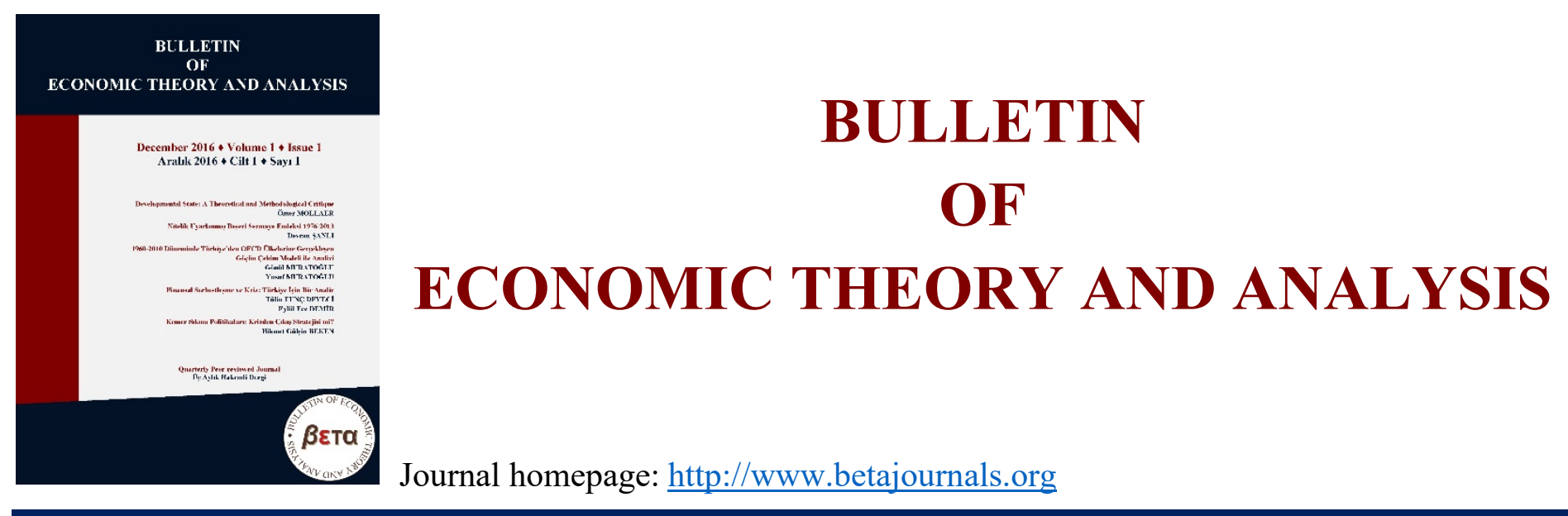

\title{
Dynamic Effects of Macroeconomic Fundamentals on Stock Market Movements: Evidence from BIST100
}

\section{Mortaza OJAGHLOU ๑ https://orcid.org/0000-0003-4580-6182}

To cite this article: Ojaghlou, M. (2020). Dynamic Effects of Macroeconomic Fundamentals on Stock Market Movements: Evidence from BIST100. Bulletin of Economic Theory and Analysis, 5(2), 17-36.

Received: 17 Mar 2020

Accepted: 13 Jul 2020

Published online: 31 Dec 2020

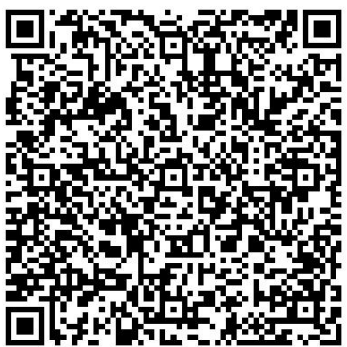




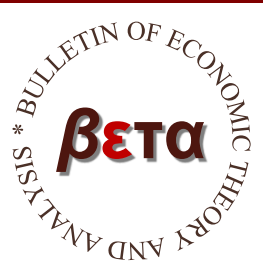

\title{
Bulletin of Economic Theory and Analysis
}

Volume V, Issue 2, pp. 17-36, 2020

http://www.betajournals.org

Original Article / Araştırma Makalesi

Received / Alınma: 17.03.2020 Accepted / Kabul: 13.07.2020

\section{Dynamic Effects of Macroeconomic Fundamentals on Stock Market Movements: Evidence from BIST100}

\author{
Mortaza OJAGHLOU ${ }^{\mathrm{a}}$
}

a Assist. Prof. Dr., Istanbul Aydin University, FEAS, Department of Economics, TURKEY

(C) https://orcid.org/0000-0003-4580-6182

\begin{abstract}
In this study we examine whether the Efficient Market Hypothesis (EMH) is valued in Turkey (BIST $100^{1}$ ) or not and we also examine the ability of essential macroeconomic variables to predict the volatility of Istanbul stock market returns. The relationship is examined through the analysis of the quarterly data concerning the Istanbul stock market index (BIST-100) and selected essential macroeconomic indicates in Turkey over the period of 2003Q01 until 2019Q01. In order to investigate the relationship between the variables and BIST-100, Phillips-Ouliaris Cointegration, Asymmetric Cointegration and Dynamic Multipliers in a Nonlinear ARDL (NLARDL) models and also Bayesian Vector Autoregression (Litterman-Minnesota Bayesian VAR) are employed. The findings of the NLARDL test indicates that variables are cointegrated and there is positive and statistically significant asymmetric long run relationship from inflation to Istanbul stock market and also GDP, nominal exchange rate, S\&P500 have significant and positive long run effect on Istanbul stock market return. These results suggest that the Istanbul stock market return (BIST-100) has consistent with the Efficient Market Hypothesis (EMH).
\end{abstract}

Keywords

BIST-100,

Stock Return

Volatility, NLARDL, Bayesian VAR,

JEL Classification E44, F65, R53, C11

CONTACT Mortaza OJAGHLOU $\square$ mortazaojaghlou@aydin.edu.tr $\Xi^{\circ}$ Istanbul Aydin University, FEAS, Department of Economics, TURKEY

\footnotetext{
${ }^{1}$ The BIST 100 index is a commonly used abbreviation for the Borsa Istanbul stock exchange, Turkey's main stock exchange
} 


\section{Introduction}

The stock market plays an important role for financial organizations and portfolio managers in the modern economics. volatility in stock market return is one of the essential tools between lenders and borrowers that help them to assessing the risk of portfolios and predicting return of future investment's income. Because predictability of volatility of stock returns help portfolios managers to minimized risks of investment in formwork of Efficient Market Hypothesis (EMH), Arbitrage Price Theory (APT) and other Asset Pricing Models. By considering related literature, those theories mainly emphasis on relationship between the stock market returns and economic activities. Also the Asset Pricing Theory and Efficient Market Hypothesis (EMH) explain the relationship between stock market and overall economic activity which it proxied by different macroeconomic variables in this case of study.

Stock market has three main important functions or effect channel through the overall economy. The first one is efficient allocation of investment resources; second one is improve of savings and better utilization of the existing resources (Leigh, 1996). According to (Fama, 1965), the Efficient Market Hypothesis (EMH) refers that stock market prices fully and rationally combine all related information. But (Alshogeathri, 2011) emphasis that some theories such as Efficient Market Hypothesis (EMH) and Arbitrage Price Theory (APT) are silent about which economic factors have the ability to influence asset prices. This silence helps to study a wide range of related economic factors to search at the different failed of economics of a stock market return, interest rate or discounted cash flows of the present value model (PVM) or the expected returns. Present Value Model (PVM) simply states that the price of a stock is the present discounted value of the expected future dividends received by the owner.

According to (McMillan, 2010) stock price (Pt) equation is as follow as:

$$
\mathrm{P}_{\mathrm{t}}=\sum_{i=1}^{\infty} \delta^{\mathrm{I}} \mathrm{E}_{\mathrm{t}} \mathrm{D}_{1+\mathrm{I}},
$$

Where; $\quad \delta=1 /\left(1+\mathrm{R}_{\mathrm{i}}\right)^{\mathrm{i}}$

$\mathrm{E}_{\mathrm{t}} \mathrm{D}_{1+\mathrm{I}}$ : Discount rate of future cash flows

Ri: Essential variables which may impact expected returns.

In other words, the stock price $(\mathrm{Pt})$ is related by RI which can be directly or indirectly affected by any macroeconomic factors. Aforementioned factors and information will be helpful 
to predict volatility of stock market. By review existing literature, there are so many empirical researches have analyzed the dynamic relationships between stock market returns and economic activity. According to (Semmler, 2006) and, (Ross, 1976) some of asset pricing theories such as APT, and the Present Value Model (PVM), refer that there is a dynamic relationship between the stock market returns and economic activities. By considering some factors such as market efficiency, the efficient market hypothesis some of the researchers such as (Asprem, 1989), (Brooks \& Del Negro, 2004), (Click \& Plummer, 2005), (Gohar et al., 2018), (Awokuse et al., 2009) and (Beine et al., 2010), focus weather stock market and economies are integrated or not. The other group of researcher such as (Hassan \& Naka, 1996), (Sohail and Hussain 2009), (Mwaanga \& Njebele, 2017) focus on short or long run relationship between macroeconomics and stock markets. Also there are some research such as (Ioannidis \& Kontonikas, 2006), (Neuhierl \& Weber, 2016), (Bjørnland \& Leitemo, 2005), and (Lütkepohl \& Netšunajev, 2018) focus on effect of monetary policy on the stock market.

\section{Literature Review}

As we noted in above, the EMH has been discussed among finance scholars more than five decades. Table 1 shows some of related researches.

Table 1.

Summary of Literature Review

\begin{tabular}{|c|c|c|c|c|}
\hline $\begin{array}{l}\text { Author(s) } \\
\text { \& Year }\end{array}$ & Country & Period & $\begin{array}{l}\text { Analysis } \\
\operatorname{method}(s)\end{array}$ & Major Results \\
\hline $\begin{array}{l}\text { (Demir, } \\
\text { 2019) }\end{array}$ & Turkey & $\begin{array}{l}\text { 2003Q1- } \\
\text { 2017Q4 }\end{array}$ & $\begin{array}{l}\text { ARDL Bounds } \\
\text { Test }\end{array}$ & $\begin{array}{l}\text { BIST100 was positively affected by } \\
\text { economic growth, exchange rate, } \\
\text { portfolio investments and foreign direct } \\
\text { investments. But effect of interest rate } \\
\text { and crude oil is negative. }\end{array}$ \\
\hline $\begin{array}{l}\text { (Soumaré \& } \\
\text { Tchana } \\
\text { Tchana, } \\
2015)\end{array}$ & $\begin{array}{l}\text { Emerging } \\
\text { economies }\end{array}$ & $\begin{array}{l}1994- \\
2006\end{array}$ & VAR & $\begin{array}{l}\text { According to this study there is } \\
\text { relationship between foreign direct } \\
\text { investment and financial market } \\
\text { development. }\end{array}$ \\
\hline $\begin{array}{l}(\mathrm{Kim} \quad \& \\
\text { Moreno, } \\
1994)\end{array}$ & Japan & $\begin{array}{l}1970- \\
1993\end{array}$ & VAR & $\begin{array}{l}\text { Increase in Japanese bank lending } \\
\text { caused to increase in Nikkei stock. } \\
\text { Therefore, there is a positive } \\
\text { relationship between them. }\end{array}$ \\
\hline
\end{tabular}




\begin{tabular}{|c|c|c|c|c|}
\hline $\begin{array}{l}\text { (Hajilee \& } \\
\text { Al Nasser, } \\
\text { 2014) }\end{array}$ & data & $\begin{array}{l}1980- \\
2010\end{array}$ & VECM & $\begin{array}{l}\text { According this study, Effect of the } \\
\text { exchange rate on stock market return in } \\
\text { China, Mexico, Pakistan and } \\
\text { Venezuela is negative } \\
\text { While for Philippines and South Africa } \\
\text { is positive. }\end{array}$ \\
\hline $\begin{array}{l}\text { (Chaudhuri } \\
\& \quad \text { Smiles, } \\
\text { 2004) }\end{array}$ & alian & $\begin{array}{l}1960- \\
1998\end{array}$ & $\begin{array}{l}\text { Johansen } \\
\text { cointegration } \\
\text { and impulse } \\
\text { response } \\
\text { function }\end{array}$ & All variables have long-run relationship. \\
\hline $\begin{array}{l}\text { (Darrat, } \\
1990)\end{array}$ & Canada & $\begin{array}{l}1972- \\
1987\end{array}$ & $\begin{array}{l}\text { Granger } \\
\text { causality }\end{array}$ & $\begin{array}{l}\text { The results show that stock market } \\
\text { efficiency hypothesis is valid in } \\
\text { Canadian stock market and Canadian } \\
\text { stock market returns are Granger caused } \\
\text { by lagged changes in fiscal deficits but } \\
\text { stock market and the monetary policy } \\
\text { don't have significant relationship with } \\
\text { each other. }\end{array}$ \\
\hline $\begin{array}{l}\text { (Gan et al., } \\
2006)\end{array}$ & $\begin{array}{l}\text { New } \\
\text { Zealand }\end{array}$ & $\begin{array}{l}1990- \\
2003\end{array}$ & $\begin{array}{l}\text { Johansen } \\
\text { cointegration, } \\
\text { Granger } \\
\text { causality tests, } \\
\text { and IRF }\end{array}$ & $\begin{array}{l}\text { According this study, variable which } \\
\text { have selected are cointegrated and also } \\
\text { there is long run relationship between } \\
\text { them. }\end{array}$ \\
\hline
\end{tabular}

\begin{tabular}{|c|c|c|c|c|}
\hline $\begin{array}{l}\text { (Rahman \& } \\
\text { Mustafa, } \\
\text { 2008) }\end{array}$ & U.S. A & $\begin{array}{l}1974- \\
2006\end{array}$ & VECM & $\begin{array}{l}\text { There is no long run relationship but the } \\
\text { result shows the exists of short run } \\
\text { relationships. }\end{array}$ \\
\hline $\begin{array}{l}\text { (Léon, } \\
\text { 2008) }\end{array}$ & Kore & $\begin{array}{l}1992- \\
1998\end{array}$ & $\begin{array}{l}\text { GARCH } \\
\text { models and } \\
\text { conditional } \\
\text { variance. }\end{array}$ & $\begin{array}{l}\text { Stock market returns and interest rate } \\
\text { have a significantly negative } \\
\text { relationship with each other. }\end{array}$ \\
\hline $\begin{array}{l}\text { (Patra \& } \\
\text { Poshakwale, } \\
\text { 2006) }\end{array}$ & Greece & $\begin{array}{l}1984- \\
2010\end{array}$ & $\begin{array}{l}\text { Granger } \\
\text { Causality Test, } \\
\text { and VECM }\end{array}$ & $\begin{array}{l}\text { The selected variable are cointegrated } \\
\text { and there are both short and long run } \\
\text { relationship between stock returns and } \\
\text { other variables. But there is no any } \\
\text { relationship between exchange rate and } \\
\text { stock returns and also Greek stock } \\
\text { market was informationally inefficient } \\
\text { during time which authors selected. }\end{array}$ \\
\hline
\end{tabular}




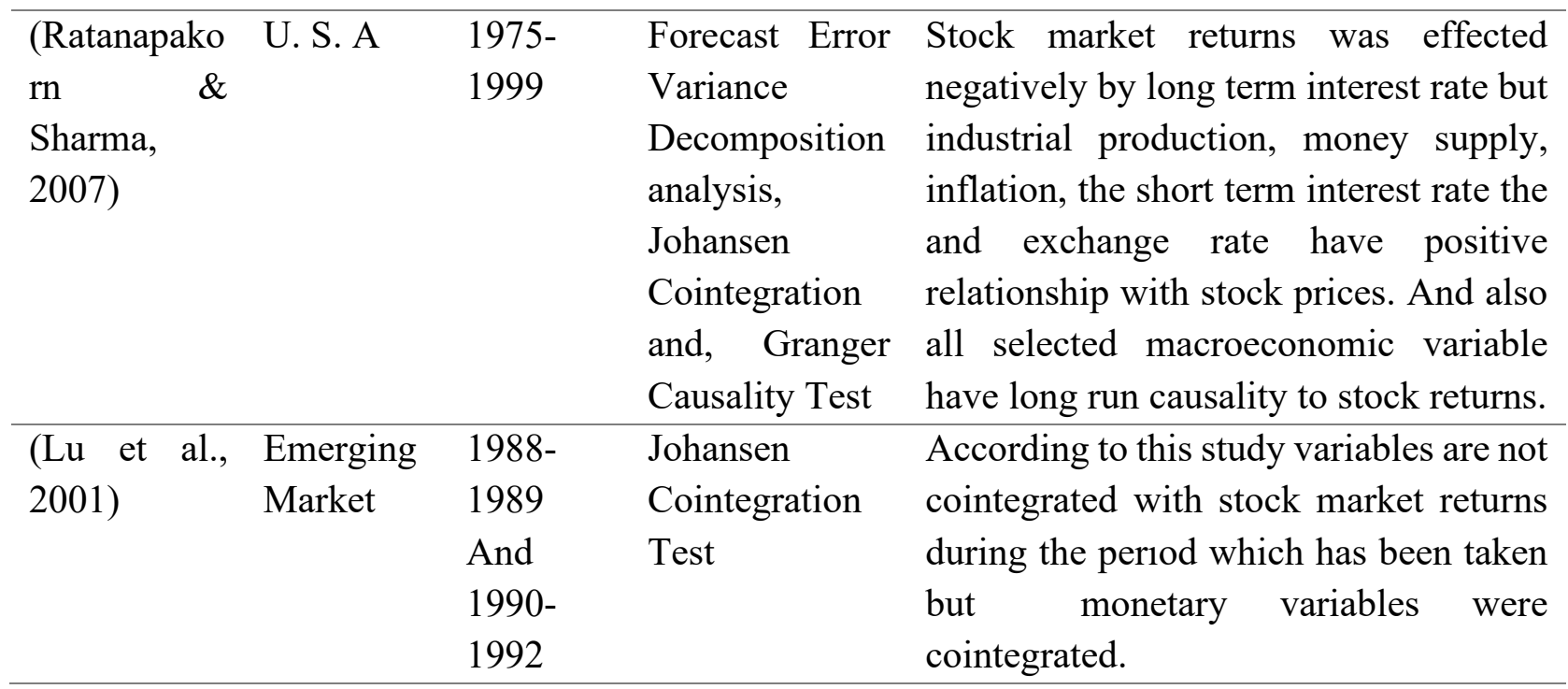

\section{Model, Data and Meteorology}

The analysis covers the period from 2003Q01 to 2019Q01 quarterly data. We selected series to analyze for three main reasons. Firstly, according to Present Value Model theory these variables theoretically have a significant effect on the stock market returns. Second, these variables are commonly used in the literature to analyze the theoretical links between stock market and real economic activities and third, these variables are available at a quarterly frequency. These macroeconomic variables ${ }^{2}$ are short-term interest rate (i), inflation in the Turkey measured by the consumer price index $(\pi)$; Brent crude price selected as proxy for world oil price, Industrial production index (IP), the nominal exchange rate of Dollar to Turkish Lira (EX), as proxy of international stock markets return Standard and Poor's 500 stock price index (S\&P 500) and Borsa Istanbul (BIST-100) as proxy for local stock market returns.

\subsection{Macroeconomic Variables in the Model}

\subsubsection{Industrial production index}

Following many researchers such as (Chen et al., 1986), (Errunza \& Hogan, 1998) and (Junttila et al., 2005), industrial production index was selected as proxy of production and also real activity. Industrial production index - which is proxy for real economic activity - is one of the most important factors that has significant effect on return of stock market.

\footnotetext{
${ }^{2}$ Source of the data for BIST-100 and S\&P-500 is https://www.investing.com, for Brent oil price, fred.stlouisfed.org and for the other series is Central bank of the Turkey and Turkish Statistical Institute (TÜIK).
} 


\subsubsection{Oil price}

Oil price is used in Bayesian VAR system as exogenous variable. Because oil prices are generally determined by world supply and demand. So there are not any economic factors which effect oil price in inside the country. (Hamilton, 1983) and (Hamilton, 1996) considered oil price changes as exogenous. Following (Hamilton, 1983), some researcher such as (Lee \& Ratti, 1995), and (Bernanke et al., 1997) maintained to use oil price as exogenous variable.

\subsection{3. İstanbul Stock Market index (BIST)}

Istanbul Stock Market Index (BIST-100), is an indicator which measures the returns of the top 100 stocks traded on Borsa Istanbul in terms of market transaction and value. XU100 is transaction code of the BIST 100 index.

\subsubsection{Short term interest rate}

Monetary policies affect economies through the credit channel that changing in availability and cost of the external funding ((Xu, n.d.) and also within Monetary policy (Bernanke, \& Blinder, 1992) emphasis that monetary shocks have effect on all economics especially have effect on small firms than on big firms. While other existing theoretical emphasis that monetary policy has no long-run impact on real stock prices (Bjørnland \& Leitemo, 2005).

\subsubsection{Inflation}

Inflation $(\pi)$ is calculated on a monthly basis from the Consumer Price Index and given on percentages that we use this data quarterly. The relationship between developed stock markets and economics variable generally reflect a negative correlation with inflation (Acikalin et al., 2008).

\subsubsection{Exchange rate}

The exchange rate is mainly linked to international competiveness. According to "good market approaches" which developed by (Dornbusch \& Fischer, 1980) focused on changes in exchange rates impact international competitiveness of firm by effect on income and cost of borrow in foreign currencies. And also according to "portfolio balance approaches" discussed by Frankel, (1993) emphasis on the role and effect of capital account transactions on determining the relationship between the exchange rate and stock market returns. 


\subsubsection{Standard and Poor's 500 Index (S\&P-500)}

Following the many researchers, we select S\&P-500 to understand how international market index effects on BIST-100. Because of effect of international crises and also using international stock to profile diversification, volatility of international stocks is so important for portfolio managers to managing profile and also for prediction of local stock markets (Alshogeathri, 2011). The S\&P-500 Index or the Standard \& Poor's-500 Index is a market capitalization weighted index of the 500 largest U.S. publicly traded companies.

\subsection{Unit Root Test}

For clarification of stationary of time series Augmented Dickey-Fuller (ADF) and PhillipsPerron (PP) unit root test has applied. Table 2 shows all variable are stationary at the I (0), I (1) and none of them is stationary at I (2). In addition, all variables seasonally adjusted.

Table 2

Unit Root Test

\begin{tabular}{|c|c|c|c|c|}
\hline \multirow[t]{2}{*}{ Variables } & \multicolumn{2}{|c|}{ ADF } & \multicolumn{2}{|c|}{$\mathbf{P P}$} \\
\hline & Intercept & $\begin{array}{l}\text { Intercept and } \\
\text { trend }\end{array}$ & Intercept & $\begin{array}{l}\text { Intercept } \\
\text { and trend }\end{array}$ \\
\hline IP & -0.60 & -2.52 & -0.45 & -2.52 \\
\hline$\Delta \mathrm{IP}$ & $-8.08 * * *$ & $-8.01 * * *$ & $-8.29 * * *$ & $-8.21 * * *$ \\
\hline OP & $-2.65^{*}$ & -2.49 & -2.13 & -1.91 \\
\hline$\Delta \mathrm{OP}$ & $-6.29 * * *$ & $-6.36 * * *$ & $-5.76 * * *$ & $-5.87 * * *$ \\
\hline$\Pi$ & $-4.66 * * *$ & $-3.41 * *$ & $-3.71 * * *$ & $-3.42 * *$ \\
\hline BIST-100 & -1.40 & $-3.81 * *$ & -1.40 & $-3.40 *$ \\
\hline$\Delta$ BIST-100 & $-7.03 * * *$ & $-6.99 * * *$ & $-7.03 * * *$ & $-6.99 * * *$ \\
\hline S\&P 500 & 0.54 & -0.86 & 0.33 & -1.09 \\
\hline$\Delta \mathrm{S} \& \mathrm{P} 500$ & $-7.11 * * *$ & $-7.24 * * *$ & $-7.14 * * *$ & $-7.24 * * *$ \\
\hline EX & 5.46 & 3.12 & 6.99 & 2.60 \\
\hline$\Delta \mathrm{EX}$ & $-6.07 * *$ & $-5.38 * * *$ & $-6.08 * * *$ & $-6.99 * * *$ \\
\hline I & $-5.31 * * *$ & $-3.22 *$ & $-4.81 * * *$ & $-3.14^{*}$ \\
\hline
\end{tabular}

Note. The sighs $* * *$ and $* * *$ represent $10 \%, 5 \%$, and less than $1 \%$ significance level, respectively.

\subsection{Single Equation Analysis : Cointegrating Regression (Residual-Based Tests)}

We consider a standard triangular representation of a regression with existence of a single cointegrating vector. cointegrating equation of $\mathrm{n}+1$ dimensional time series vector for $\mathrm{y}_{\mathrm{t}}, \mathrm{x}_{\mathrm{t}}{ }^{\prime}$ is: 
$\mathrm{y}_{\mathrm{t}}=\mathrm{x}_{\mathrm{t}}^{\prime} \beta+D_{1 t}^{\prime} \gamma_{1}+\mathrm{u}_{1 \mathrm{t}}$

where $D_{t}=\left(D_{1 t}^{\prime}, D_{2 t}^{\prime}\right)^{\prime}$, n: stochastic regressors and $x_{t}=\tau_{21}^{\prime} D_{1 t}+\tau_{22}^{\prime} D_{2 t}+\varepsilon_{2 t}$ where $\Delta \varepsilon_{2 \mathrm{t}}=\mathrm{u}_{2 \mathrm{t}}$

Alternative hypothesis of null hypothesis of no cointegration is cointegration which corresponds to the null of nonstationary against the alternative of stationarity. For p-lag augmented regression form:

$\Delta u_{1 t}=(\rho-1) u_{1 t-1}+\sum_{j=1}^{p} \delta_{j} \Delta u_{1 t-j}+v_{t}$

where,

$\hat{\tau}=\frac{\hat{\rho}-1}{\operatorname{se}(\hat{\rho})} \quad$ and $\hat{z}=\frac{T(\hat{\rho}-1)}{1-\Sigma_{j} \hat{\delta}_{j}} \quad ; \operatorname{se}(\hat{\rho})$ for usual estimator of the standard error of the estimaton $\hat{\rho}$ :

$$
\operatorname{se}(\hat{\rho})=\hat{s}_{v}\left(\sum_{t} u_{1 t-1}^{2}\right)^{-1 / 2},
$$

Some of the variables are not stationary at the level, therefore for Phillips-Ouliaris analyses first differences of non-stationary variable is taken. Following to literature the baseline Cointegrating Regression model is obtained as follow as:

Change in BIST-100 index $=\mathrm{f}$ (growth of industrial production, Interest rate, change in exchange rate, inflation rate, change in sp500 index)

Table 3

Phillips-Ouliaris Cointegration Test

\begin{tabular}{cc}
\hline Parameters & $\begin{array}{c}\text { Phillips-Ouliaris Cointegrating } \\
\text { Regression }\end{array}$ \\
\hline$\hat{\tau}$ & $-4.76^{* *}$ \\
$z$ & $-33.90^{* *}$ \\
\hline$\hat{\rho}^{-1}$ & -0.62 \\
\hline$\hat{\rho}^{*}-1$ & -0.616 \\
\hline$\hat{\rho}^{*}$ S.E & 0.129
\end{tabular}

Note: sighs $* * *$ represent $1 \%$ significance level.

According table 3 variables are cointegrated. In case of using growth or change of nonstationary series, series has lost its long run feature. NLARDL allows use to use combination of 
I(0) and I(1). Therefore, by using Nonliner ARDL model we will test cointagration, short and long run relationship between variables at level.

NLARDL model developed by (Greenwood-Nimmo et al., n.d.) and (Shin et al., 2011) that refer to combines a non-linear long run relationship with nonlinear and asymmetric error correction by use of constructed partial sum decompositions.

NLARDL long-run relationship:

$$
y_{t}=\beta^{+} x_{t}^{+}+\beta^{-} x_{t}^{-}+u_{t}
$$

Where $\mathrm{x}_{\mathrm{t}}$ is a $\mathrm{k} \times 1$ vector and $x_{t}=x_{0}+x_{t}^{+}+x_{t}^{-}$

Where $\mathrm{x}^{\mathrm{pos}}$ and $\mathrm{x}_{\mathrm{t}}{ }^{\text {neg }}$ are partial sum processes of positive and negative changes in $\mathrm{x}_{\mathrm{t}}$ defined by

$$
x_{t}^{+}=\sum_{j=1}^{t} \Delta x_{j}^{+}=\sum_{j=1}^{t} \max \left(\Delta x_{j}, 0\right), x_{t}^{-}=\sum_{j=1}^{t} \Delta x_{j}^{-}=\sum_{j=1}^{t} \min \left(\Delta x_{j}, 0\right)
$$

And $\beta^{\text {pos }}, \beta^{\text {neg }}$ are the related asymmetric long-run elements. error-correction form of the system is as follows:

$\Delta y_{t}=\rho y_{t-1}+\theta^{+} x_{t-1}^{+}+\theta^{-} x_{t-1}^{-}+\sum_{j=1}^{p-1} \gamma_{j} \Delta y_{t-j}+\sum_{j=0}^{q}\left(\pi_{j}^{+} \Delta x_{t-j}^{+}+\pi_{j}^{-} \Delta x_{t-j}^{-}\right)+\varepsilon_{t}$

where null hypothesis $\rho=\theta^{\text {pos }}=\theta^{\text {neg }}=0$

long-run steady state of the system can be written as follows by the asymmetric cumulative dynamic multipliers:

$$
\begin{aligned}
& m_{h}^{+}=\sum_{j=0}^{h} \partial y_{t+j} / \vartheta x_{t}^{+} \quad \mathrm{h}=0,1,2, \ldots \\
& m_{h}^{-}=\sum_{j=0}^{h} \partial y_{t+j} / \vartheta x_{t}^{-}
\end{aligned}
$$

where $^{m_{h}^{+}}$and $m_{h}^{-}$tend toward the respective asymmetric long-run coefficients $\beta^{+}=\theta^{+} /-\rho$ and $\beta^{-}=\theta^{-} /-\rho$, respectively, as $\mathrm{h} \rightarrow \infty$.

In our case of asymmetric or Non-linear ARDL (NLARDL): 


$$
\begin{aligned}
& \Delta B I S T 100_{t}= \\
& =\alpha_{0}+\sum_{q=1}^{p 1} \alpha_{1 q} \Delta B I S T 100_{i, t-q}+\sum_{q=0}^{p 2} \alpha_{2 q} \Delta \pi_{i, t-q}^{p o s}+\sum_{i, t-1}^{p 3} \alpha_{3 q} \Delta \pi_{i, t-q}^{n e g}+\sum_{i, t-1}^{p 4} \alpha_{4 q} \Delta I P_{i, t-q}+\sum_{q=0}^{p 5} \alpha_{5 q} \Delta E X_{i, t-q}+ \\
& \sum_{q=0}^{p 5} \alpha_{6 q} \Delta I_{i, t-q}+\sum_{q=0}^{p 6} \alpha_{7 q} \Delta S P 500_{i, t-q}+\beta_{1} B I S T_{i, t-1}+\beta_{2} I P_{i, t-1}+\beta_{3} E X_{i, t-1}+\beta_{4} I_{i, t-1}+\beta_{5} \pi_{i, t-1}^{p o s}+\beta_{6} \pi_{i, t-1}^{n e g}+\varepsilon_{t}
\end{aligned}
$$

Because of important rule of inflation on monetary policy and also in real economic activity, Inflation is selected as asymmetric variable in Non-ARDL equation.

\begin{tabular}{|c|c|c|}
\hline \multirow[t]{3}{*}{ Variables } & \multicolumn{2}{|r|}{ NLARDL Model $(1,1,3,0,0,2,3)$} \\
\hline & Long Run & Short Run Relationship From Variables to BIST-100 (f-stat) \\
\hline & Coefficients & \\
\hline $\mathrm{C}$ & $132259.8 * * *$ & -- \\
\hline$\pi^{p o s}$ & $3490.49 * * *$ & $14.93 * * *$ ( There is short run relationship) \\
\hline$\pi^{\text {neg }}$ & $4390.49 * * *$ & $4.02 * *$ ( There is short run relationship) \\
\hline IP & 183.20 & 0.04 (no short run relationship) \\
\hline I & $-4391.65 * * *$ & 0.17 (no short run relationship) \\
\hline EX & 7571.908 & $3.59 * *$ ( There is short run relationship) \\
\hline S\&P500 & $38.74 * * *$ & $6.71 * * *($ There is short run relationship) \\
\hline F-Bounds & $4.400 * * *$ & -- \\
\hline $\mathrm{ECt}-1$ & $-0.54 * * *$ & -- \\
\hline Breusch- & dfrey- Serial & $\mathrm{F}=1.52(0.22)$ \\
\hline
\end{tabular}

Table 4

Direct Long and Short Run Effect on BIST-100

Note. The sighs $* * *$ following the t-statistics represent $1 \%$ significance level, and parantes shows probability.

This result of NLARDL in Table 4 indicates that all selected variables have long run relationship and they are cointegrated. Therefore, this result of NLARDL was consistent with the 
result of the Phillips-Ouliaris cointegration test. According to results of NLARDL there is long run positive relationship between Istanbul stock market index and macroeconomic variables. While, just short term interest rate (i) has statistically significant and negative long run relationship with Istanbul stock market. The Industrial production and short-term interest rate have no significant short run effect on BIST-100. While other variables have statistically significant and short run effect on BIST-100.

\subsection{Bayesian VARs and Impulse Response Functions}

Bayesian analysis is required to have knowledge of the distributional properties of the prior, likelihood, and posterior. The prior distributional is the external distributional information which reflects researchers' beliefs on parameters of research and interest.

For setting distributional properties of the prior are followed a normal prior on with fixed $\sum_{\varepsilon}$ Litterman or Minnesota prior method. According to (Doan et al., 1986) and (Litterman, 1986) priors is based on an assumption that $\sum_{\varepsilon}$ is known as prior elicitation and computation of the posterior.

Since $\sum_{\varepsilon}$ is replaced by . The Litterman prior assumes that the prior of $\theta$ is

$$
\hat{\Sigma}_{\epsilon} \quad \theta \sim \mathrm{N}\left(\theta_{0}, \mathrm{~V}_{0}\right)
$$

$\mathrm{V}_{0}$ is a diagonal matrix with elements $V_{l j}^{1}$ for $\mathrm{I}=1, \ldots \mathrm{p}$

$$
v_{l j}^{1}= \begin{cases}\left(\frac{\lambda_{1}}{\lambda_{3}}\right)^{2} & \text { for } \mathrm{i}=\mathrm{j} \\ \left(\frac{\lambda_{1} \lambda_{2} \sigma_{i}}{{ }_{1} \lambda_{3} \sigma_{j}}\right)^{2} & \text { for } \mathrm{i} \neq \mathrm{j}\end{cases}
$$

where $\sigma_{i}^{2}$ is the $\mathrm{i}$ th diagonal element of $\sum_{\varepsilon}$. This prior setting indicates that the complicated choice of specifying all the elements of down to choosing three scalars, and; $\lambda_{1}$ measures the tightness of the prior:

When $\lambda_{1}=0$ the prior is imposed exactly, while as $\lambda_{1}=\infty$ estimates will reflect the Ordinary Least Squares. $\lambda_{2}$ reflects the standard deviation of the prior on lags of variables other than the dependent variable. And $\lambda_{2}=1$ there is no distinction between lags of the dependent variable and other variables. $\lambda_{3}$ controls the decay over lags. 
According to (Marcellino et al., 2012) and (Giannone et al., 2015) there are ways to choose hyperparameters optimally. While considering our hypotheses and also following (Carriero, n.d.). The priors parameters were improve with new alternatives for forming the underlying covariance matrices that make up essential additives of the prior. The covariance matrices and related earlier specification are generally formed by specifying a matrix alongside a number of hyper-parameters which define any non-zero factors of the matrix. The hyper-parameters themselves are both selected by the researcher, or taken from an initial error covariance estimate. Sensitivity of the posterior distribution to the selection of hyper-parameter is a well researched topic, with practitioners often choosing many unique hyper-parameter values to check their analysis does no longer change based completely on preference of parameter. $\mu 6$ is related to initial observation dummies which is not set up in our models. we set hyperparameters which shown in table 5;

Table 5

Bayesian VAR Litterman-Minnesota Hyperparameters:

\begin{tabular}{cc}
\hline $\mathbf{A R}(\mathbf{1})$ & $\mathbf{0}$ \\
\hline $\boldsymbol{\mu 6}$ & $\begin{array}{c}\text { There is no initial observation } \\
\text { dummies }\end{array}$ \\
\hline $\boldsymbol{\lambda}_{\mathbf{0}}$ & 0 \\
\hline $\boldsymbol{\lambda}_{\mathbf{1}}$ & 0.2 \\
\hline $\boldsymbol{\lambda}_{\mathbf{2}}$ & 1 \\
\hline $\boldsymbol{\lambda}_{\mathbf{3}}$ & 1
\end{tabular}

According to some studies such as (Ashley \& Verbrugge, 2009) modeled a VAR in levels to apply IRF confidence interval estimation perform adequately. Also (Ojaghlou, 2019), (Rüffer \& Stracca, n.d.), (Sousa \& Zaghini, 2008), use I(0) instead of I(1) variables to IRF. Therefore, level of HP-filtered series used to 10 period of IRF of Bayesian VAR. The result summarized Figure 1. 


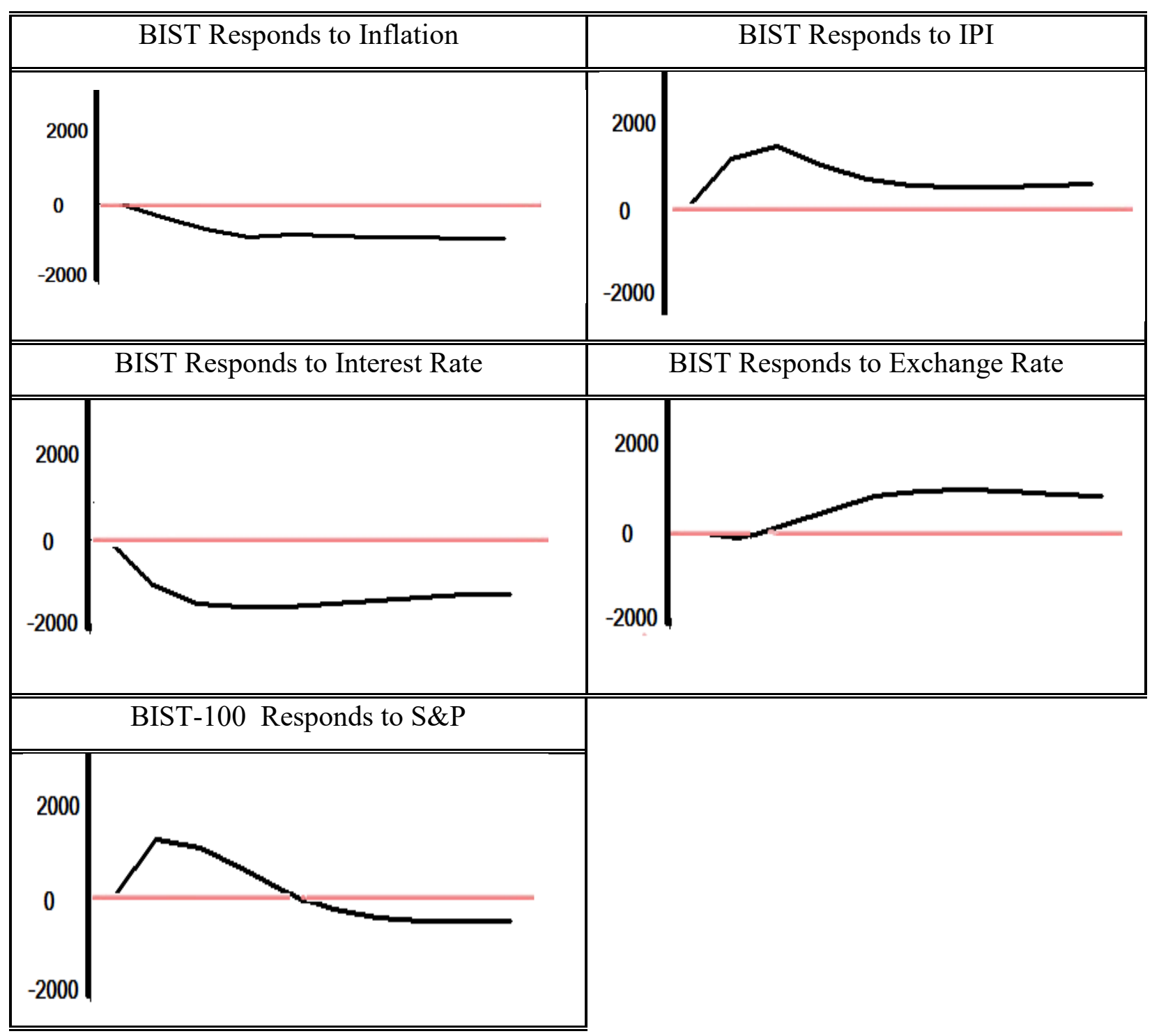

Figure 1. Impulse Response Functions of Bayesian VAR (Litterman-Minnesota)

Based on panels in Figure 1 the Impulse Respond Functions (IRF) indicate that the effects of inflation and interest rate on BIST are negative. Our results is same with (Alshogeathri, 2011) and (Bjørnland \& Leitemo, 2005). Effect of Income and exchange rate are positive. The effect of $\mathrm{S} \& \mathrm{P}$ on BIST partly is positive. Except inflation the result of Bayesian VAR is generally same with results of NLARDL. Also we test dual-side causality between BIST and inflation which shows there is generally negative relationship between inflation and BIST. The international stock market shocks (S\&P 500) has generally positive affect to BIST-100. BIST-100 responds positively to nominal exchange rate that shows BIST-100 has been used as asset to keep value. 


\section{Conclusion and Implications}

The main objective of this study is to analyses whether the most important macroeconomic factors selected in this study have long and short run effect on the Istanbul stock market returns or not. The other word, long and short runs dynamic relationships between BIST-100 and essential macroeconomic variables over the period from 2003Q01-2019Q01 are examined.

Bayesian VARs models including the Phillips-Ouliaris cointegration test, NLARDL test impulse response functions analysis were used to estimate the short and long run relationships between the selected macroeconomic series and the Istanbul stock market (BIST-100).

By considering unit root test, we use growth and changes of variables to use the PhillipsOuliaris cointegration test. The results suggest that macroeconomic variables have long run relationship that it indicate each variable in the system tends to adjust proportionally to bring in the system back to its long run equilibrium. Also for testing both long and short run relationship NLARDL method were used that the results indicate all selected variable are cointegrated and there is long run relationship in between variables.

The findings of the NLARDL test indicate that there is significant and positive asymmetric long run relationship from inflation to Istanbul stock market and IP, nominal exchange rate, S\&P500 had significant and positive long run effect on Istanbul stock market return. However IP shows no significant effect on Istanbul stock. While only short-term interest rate affected negatively. These results suggest that the Istanbul stock market price has consistent with the efficient market hypothesis (EMH).

The Bayesian VAR - IRF analysis shows evidence that there are significant long run relationships between the Istanbul stock market returns and all other macroeconomic variables that show the findings of IRF are consistent with the EMH and financial theories.

As implication Istanbul stock market returns mainly are predictable as the volatility of macroeconomic variables especially in the long run. Financier in the Istanbul stock market should consider change and volatility revealed by the monetary policy driven by short term interest rates, inflation, oil price, nominal exchange rates, and the international stock market. Efficient market hypothesis (EMH) is mainly valued in Turkey and it should be considered by finance and monetary authorities when they plan financial policies. Also this study by using oil price as exogenous 
variable may help to understand role of the oil in financial sector for non-oil exporter countries such as Turkey. 


\section{References}

Acikalin, S., Aktas, R. \& Unal, S. (2008). Relationships between stock markets and macroeconomic variables: An empirical analysis of the Istanbul Stock Exchange. Investment Management and Financial Innovations, 5(1), 10.

Alshogeathri, A. M. (2011). Macroeconomic Determinants of the Stock Market Movements: Empirical Evidence from the Saudi Stock Market,. PHD Thesis Department of Economics, Kansas State University.

Ashley, R. A. \& Verbrugge, R. J. (2009). To difference or not to difference: A Monte Carlo investigation of inference in vector autoregression models. International Journal of Data $\begin{array}{lllll}\text { Analysis Techniques } & \text { and }\end{array}$ https://doi.org/10.1504/IJDATS.2009.024295

Asprem, M. (1989). Stock prices, asset portfolios and macroeconomic variables in ten European countries. Journal of Banking \& Finance, 13(4-5), 589-612. https://doi.org/10.1016/03784266(89)90032-0

Awokuse, T. O., Chopra, A. \& Bessler, D. A. (2009). Structural change and international stock market interdependence: Evidence from Asian emerging markets. Economic Modelling, 26(3), 549-559. https://doi.org/10.1016/j.econmod.2008.12.001

Beine, M., Cosma, A. \& Vermeulen, R. (2010). The dark side of global integration: Increasing tail dependence. Journal of Banking \& Finance, 34(1), 184-192. https://doi.org/10.1016/j.jbankfin.2009.07.014

Bernanke, B. S., Gertler, M., Watson, M., Sims, C. A. \& Friedman, B. M. (1997). Systematic monetary policy and the effects of oil price shocks. Brookings Papers on Economic Activity, 1997(1), 91. https://doi.org/10.2307/2534702

Bernanke, Ben S. \& Alan S. Blinder. (1992). The federal funds rate and the channels of monetary transmission. The American Economic Review, 82(2), 901-921.

Bjørnland, H. C. \& Leitemo, K. (2005). Identifying the Interdependence between US Monetary Policy and the Stock Market (SSRN Scholarly Paper ID 1018594). Social Science Research Network. https://papers.ssrn.com/abstract $=1018594$

Brooks, R. \& Del Negro, M. (2004). The rise in comovement across national stock markets: Market integration or IT bubble? Journal of Empirical Finance, 11(5), 659-680. https://doi.org/10.1016/j.jempfin.2003.08.001

Carriero, A. (n.d.). Separately, each of the two equations constitutes a restricted ADL model: Same \#lags for both Y1,t and Y2,t in both equations. Current value of additional explanatory variable ("Xt") is ruled out. 69. 
Chaudhuri, K. \& Smiles, S. (2004). Stock market and aggregate economic activity: Evidence from Australia. Applied Financial Economics, 14(2), 121-129.

Chen, N.-F., Roll, R. \& Ross, S. (1986). Economic forces and the stock market. The Journal of Business, 59(3), 383-403.

Click, R. W. \& Plummer, M. G. (2005). Stock market integration in ASEAN after the Asian financial crisis. Journal of Asian Economics, 16(1), 5-28. https://doi.org/10.1016/j.asieco.2004.11.018

Darrat, A. F. (1990). Stock returns, money, and fiscal deficits. Journal of Financial and Quantitative Analysis, 25(3), 387-398. https://doi.org/10.2307/2330703

Demir, C. (2019). Macroeconomic determinants of stock market fluctuations: The case of BIST100. Economies, 7(1), 8. https://doi.org/10.3390/economies 7010008

Doan, T., Litterman, R. \& Sims, C. (1986). Forecasting and conditional projection using realistic prior distribution. Econometric Reviews, 3(1).

Dornbusch, R. \& Fischer, S. (1980). Exchange rates and the current account. American Economic Review, 70(5), 960-971.

Errunza, V. \& Hogan, K. (1998). Macroeconomic determinants of european stock market volatility. European Financial Management, 4(3), 361-377. https://doi.org/10.1111/1468036X.00071

Fama, F. E. (1965). The behavior of stock-market prices. Journal of Business, 38, 34-105.

Frankel, J. A. (1993) Monetary and Portfolio -Balan ce Models of the Determination of Exchange Rates. Cambridge and London: MIT Press. - Yahoo Search Results. (n.d.). Retrieved

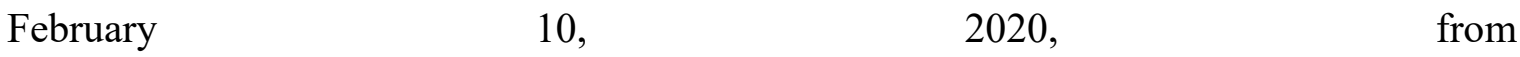
https://search.yahoo.com/search?fr=mcafee\&type=E210US91105G0\&p=Frankel\%2C+J.+ A.+(1993)+Monetary+and+Portfolio+-

Balan + ce + Models + of + the + Determination + of + Exchange + Rates. + Cambridge + and + Londo $\mathrm{n} \% 3 \mathrm{~A}+\mathrm{MIT}+$ Press.

Gan, C., Lee, M., Yong, H. H. A. \& Zhang, J. (2006). Macroeconomic variables and stock market interactions: New Zealand evidence. Investment Management and Financial Innovations, 3(4). https://businessperspectives.org/journals/investment-management-and-financialinnovations/issue-65/macroeconomic-variables-and-stock-market-interactions-newzealand-evidence

Giannone, D., Lenza, M. \& Primiceri, G. (2015). Prior selection for vector autoregressions. The Review of Economics and Statistics, 97(2), 436-451.

Gohar, R., Shah, S. Z. A. \& Ahmad, H. (2018). Economic integration and stock market comovement: An empirical study pairing Pakistanâ $€^{\mathrm{TM}_{\mathrm{S}}}$ stock exchange with 21 other markets. Journal of Reviews on Global Economics, 7, 28-36. 
Greenwood-Nimmo, M., Shin, Y. \& van Treeck, T. (n.d.). The Asymmetric ARDL Model with Multiple Unknown Threshold Decompositions: An Application to the Phillips Curve in Canada * Preliminary and incomplete-Do not cite without permission.

Hajilee, M. \& Al Nasser, O. (2014). Exchange rate volatility and stock market development in emerging economies. Journal of Post Keynesian Economics, 37(1), 163-180.

Hamilton, J. D. (1983). Oil and the macroeconomy since World War II. Journal of Political Economy, 91(2), 228-248. https://doi.org/10.1086/261140

Hamilton, J. D. (1996). This is what happened to the oil price-macroeconomy relationship. Journal of Monetary Economics, 38(2), 215-220. https://doi.org/10.1016/S0304-3932(96)01282-2

Hassan, M. K. \& Naka, A. (1996). Short-run and long-run dynamic linkages among international stock markets. International Review of Economics \& Finance, 5(4), 387-405. https://doi.org/10.1016/S1059-0560(96)90025-8

Ioannidis, C. \& Kontonikas, A. (2006). Monetary policy and the stock market. 25.

Junttila, J., Kallunki, J.-P., Karja, A. \& Martikainen, M. (2005). Stock market response to analysts' perceptions and earnings in a technology-intensive environment. International Review of Financial Analysis, 14(1), 77-92.

Kim, S. B. \& Moreno, R. (1994). Stock prices and bank lending behavior in Japan. Economic Review, 31-42.

Lee, K. S. N. \& R. A. Ratti. (1995). Oil shocks and the macroeconomy: The role of price variability. Energy J., 16(4), 39-56.

Leigh, L. \& Amin Y. (1996). Stock market equilibrium and macroeconomic fundamentals. International Monetary Fund, Washington, DC., IMF Working Paper WP/97/15.

Léon, K. N. (2008). The effects of interest rates volatility on stock returns and volatility: Evidence from Korea. International Research Journal of Finance and Economics, 14, 285-290.

Litterman, R. B. (1986). Forecasting with Bayesian vector autoregressions: Five years of experience. Journal of Business \& Economic Statistics, 4(1), 25-38. JSTOR. https://doi.org/10.2307/1391384

Lu, G. M., Metin, K. \& Argac, R. (2001). Is there a long run relationship between stock returns and monetary variables: Evidence from an emerging market. Applied Financial Economics, 11(6), 641-649. https://doi.org/10.1080/09603100110094411

Lütkepohl, H. \& Netšunajev, A. (2018). The relation between monetary policy and the stock market in Europe. Econometrics, 6(3), 36. https://doi.org/10.3390/econometrics6030036

Marcellino, M., Carriero, A. \& Clark, T. E. (2012). Real-time nowcasting with a Bayesian mixed frequency model with stochastic volatility (No. 1227; Working Papers (Old Series)). Federal Reserve Bank of Cleveland. https://ideas.repec.org/p/fip/fedcwp/1227.html 
McMillan, D. G. (2010). Present value model, bubbles and returns predictability: Sector-level evidence. Journal of Business Finance \& Accounting, 37(5-6), 668-686. https://doi.org/10.1111/j.1468-5957.2009.02176.x

Mwaanga, C. \& Njebele, N. (2017). The long-run and short-run relationship between the exchange rates and stock market prices. Journal of Financial Risk Management, 06(04), 315-324. https://doi.org/10.4236/jfrm.2017.64023

Neuhierl, A. \& Weber, M. (2016). Monetary Policy and the Stock Market: Time-Series Evidence (Working Paper No. 22831). National Bureau of Economic Research. https://doi.org/10.3386/w22831

Ojaghlou, M. (2019). Tourism-led growth and risk of the Dutch disease: Dutch disease in Turkey. International Business Research, 12(7), 103-120.

Patra, T. \& Poshakwale, S. (2006). Economic variables and stock market returns: Evidence from the Athens stock exchange. Applied Financial Economics, 16(13), 993-1005. https://doi.org/10.1080/09603100500426523

Rahman, M. \& Mustafa, M. (2008). Influences of Money Supply and Oil Price on U.S. Stock Market.

Ratanapakorn, O. \& Sharma, S. C. (2007). Dynamic analysis between the US stock returns and the macroeconomic variables. Applied Financial Economics, 17(5), 369-377. https://doi.org/10.1080/09603100600638944

Ross, S. A. (1976). The arbitrage theory of capital asset pricing. Journal of Economic Theory, 13(3), 341-360. https://doi.org/10.1016/0022-0531(76)90046-6

Rüffer, R. \& Stracca, L. (n.d.). What is global excess liquidity, and does it matter? 52.

Semmler, W. (2006). Asset Prices, Booms and Recessions: Financial Economics from a Dynamic Perspective (2nd ed.). Springer-Verlag. https://doi.org/10.1007/b106192

Shin, Y., Yu, B. \& Greenwood-Nimmo, M. (2011). Modelling Asymmetric Cointegration and Dynamic Multipliers in a Nonlinear ARDL Framework. SSRN Electronic Journal. https://doi.org/10.2139/ssrn.1807745

Sohail, N. \& Hussain, Z. (2009). Long-Run and Short-Run Relationship between Macroeconomic Variables and Stock Prices in Pakistan: The Case of Lahore Stock Exchange. Pakistan Economic and Social Review, 47(2), 183-198.

Soumaré, I. \& Tchana Tchana, F. (2015). Causality between FDI and financial market development: Evidence from emerging markets. World Bank Economic Review, 29, 205216.

Sousa, J. \& Zaghini, A. (2008). Monetary policy shocks in the euro area and global liquidity spillovers. International Journal of Finance \& Economics, 13(3), 205-218. https://doi.org/10.1002/ijfe.320 
$\mathrm{Xu}$, J. (n.d.). Interest Rate Uncertainty and Stock Market Volatility. 53. 